PERAET 2021

International Scientific Conference «PERISHABLE AND ETERNAL: Mythologies and Social

Technologies of Digital Civilization-2021»

\title{
REGIONAL VARIANTS OF THE RUSSIAN LITERARY LANGUAGE: SITUATION IN SEVASTOPOL
}

\author{
Yuriy L. Sitko (a)*, Olga G. Rovnova (b), Olga A. Kuzina (c) \\ *Corresponding author
}

(a) Moscow State University Branch in Sevastopol (MSU), Sevastopol, Russian Federation, yurii.sitko@gmail.com,

(b) Vinogradov Russian Language Institute of the Russian Academy of Sciences, Moscow, Russian Federation, supilinn@mail.ru,

(c) Moscow State University Branch in Sevastopol (MSU), Sevastopol, Russian Federation, mojipisma@yandex.ru

\begin{abstract}
The article is devoted to the issue of a certain variant of the Russian language functioning in Sevastopol and Crimea. It provides findings of the study, which took several years, and involved examination of the speech of Sevastopol residents. On the basis of comparing the local speech with some other southern Russian vernacular the main features of the speech of Sevastopol residents are demonstrated. The following dominating characteristics are pointed out: absence of convergence of sounds [i] and [y], absence of diphthongization of stressed vowels, reduction of vowels in an unstressed position, as well as contrasting of phonemes $\left.\left\langle_{\Gamma}\right\rangle,<^{\prime}\right\rangle,\langle\gamma\rangle$ and $\left\langle\gamma^{\prime}\right\rangle$. Moreover, phonemes $\langle\mathrm{v}\rangle$ and $\left\langle\mathrm{v}^{\prime}\right\rangle$ are regularly realised by bilabial sounds turning voiceless close to $[\mathrm{f}]$ and $\left[\mathrm{f}^{\prime}\right]$, while allophones $[\mathrm{w}],\left[\mathrm{w}^{\prime}\right],\left[\mathrm{y}^{`}\right]$ characteristic of the southern Russian dialects and the Ukrainian language are hardly ever met. Derivational means are mostly applied in the sphere of locality with a wide range of agoronyms, godonyms, horonyms. However, Sevastopol urbanonyms are represented only by nominals and created by suffixation. The author concludes that the findings prove the absence of a certain variant of the Russian language in Crimea and Sevastopol, with some deviations from the literary norm characteristic of the subdialects of southern Russia being present.
\end{abstract}

2357-1330 @ 2021 Published by European Publisher.

Keywords: Contact vernacular, literary norm, national language variant, Russian language, urban vernacular 


\section{Introduction}

In recent decades there has been an active process of continuous stratification of the language with the spoken informal varieties being more and more differentiated from the written literary norm which inevitably triggers the interest of linguists. For example, many European researchers pay attention to the description of slang in its correlation to jargon and argot in English (Neshkovska, 2020; Selmistraitis \& Boikova, 2020), Lithuanian (Kudirka, 2019). The studies show that in modern urban language environment, especially among young people, due to constant contact between English and local Slavic languages, in particular Macedonian, some kind of anti-language springs into existence (Neshkovska, 2020). Besides, functioning of the language in discourses generated by urban surrounding gives rise to special form of modality which is peculiar for people of certain professions both in Russian (Nemickiené, 2019) and in English (D’Arcey et al., 2019). Researchers have witnessed active pragmaticalisation of some speech patterns (Uryson, 2020), in particular those of saying goodbye (Bobrik, 2021). Moreover, scientists have noticed some deviations in grammar constructions connected with territorial (dialectal) rather than social stratification of the Russian language (Malysheva \& Ronko, 2020; Rovnova, 2020). There are also some studies of the sign Russian language (Fedorova, 2018).

The Russian language functioning in current conditions raises interest among the Russian linguists which is reflected in profound scientific research (Chobanyan et al., 2020; Gantsovskaia \& Neganova, 2020; Sitko, 2017). Linguistic novelties arising in the Russian language of the residents of the southern Ukraine and its neighbouring regions are also actively investigated (Amirov, 2021; Antonenko \& Teplova, 2019).

Situation witnessed in Crimea and Sevastopol at the end of the 20th - beginning of the 21st century is not typical for the functioning of the Russian language. On the one hand, urban vernacular was differentiable and in active circulation in Crimea and Sevastopol (it is characteristic of the Russian language (Shalina, 2009; Shmeleva, 2014) and was noticed back in 1920s. On the other hand, functioning of the Russian language in Crimea was restricted: teaching hours of Russian were substantially reduced which resulted in poor competence of school-leavers in the literary language and its norms; teaching hours of the Ukrainian language were increased instead. According to the opinion of politicians and scientists, this should start influencing the language system in the minds of the native Russian-speakers in Crimea. So the background was created for intensification of language processes in the Russian language of the Crimean residents towards convergence with the Ukrainian language, eliminating language signs of social stratification and weakening of the literary norm, which in turn could lay the foundation for the formation of a distinct variant of the Russian language in Crimea.

\section{Problem Statement}

This situation was reflected in the scientific speculations of the Crimean linguists. In a series of his works, Rudyakov (2010) proposed the idea of differentiating Russian and non-Russian variants of the Russian language and formation of the Ukrainian variant of the Russian language in Crimea and Ukraine. However, this idea faced with criticism both among pro-Ukrainian and pro-Russian commentators. For instance, Terkulov (2012), one of the most prudent and scrupulous critics of A. Rudyakov, remarks that 
national language, national variant of the language is tied not to the ontological reality, is not based primarily on the absolutization of some language features of this or that dialect but represents some type of convention $<\ldots>$ similar national identity of the speakers of these dialects different from the national identity of the speakers of other dialects of the same language metropole. (p. 120)

Let us remark that both these scientists stand on identical positions: they rely on the political reality but pursue different goals.

\section{Research Questions}

We consider that the root of the problem raised by A. Rudyakov may lie in determining the underlying features on the basis of which one will be able to distinguish a variant of the national language as a structural whole possessing its own ontics from such social phenomena as contact vernacular, urban vernacular, slang or dialect. Moreover, the prerequisite of determining such features should be not the difference in separate elements of the system but substantial difference in structures.

In this aspect the definition of dialect does not pose any problem: traditionally it is understood as a rural, suburban phenomenon, so in the current conditions of growing urbanization its influence on the functioning of the national language can be left aside.

Urban vernacular is in turn defined as speech practice of lower strata of urban community. It bares social character for researchers, which was rightly remarked by Kudriavtseva (2005). Proponents of this idea look at the issue predominantly from the lexicological angle. For instance, Rozina (2002, p. 2) uses the term 'general sla' for the words widespread among all strata of the urban community and being on the outskirts of the literary norm. Khimik (1998) also ties urban vernacular to slang. However, recent years have been characterized by levelling out of the social status of urban population and disappearance of speech differentiation of social stratification. Consequently, we consider it possible to contrast urban vernacular to general slang as much as we contrast general to special.

This conclusion allows us to pass on to the contrast of urban vernacular and literary language. We tend to consider urban vernacular as something characteristic of urban residents irrespective of their social status and functioning as a spoken variant of the language serving everyday rather than formal speech situations. Consequently, requirements of the literary norm in the sphere of urban vernacular are followed by the speakers inasmuch as they represent ethical and communicative norms while purely linguistic component of the norm ceases to be a subject of interlocutors 'reflection. Strictly speaking, urban vernacular is a form of language functioning when literary language norms are indifferent for interlocutors.

So, we believe that in current conditions urban vernacular is characterized not by its lexical differences from the literary language but mostly by similarities of its grammatical (derivational, inflectional and syntactic) and phonetic system with the systems of the literary language. Under this approach, the idea of a national variant of the language appears to be very productive: if urban vernacular starts losing its connection to the systems of a national language we can speak of a national variant of a 
language. Using the images of academician L. Shcherba, we may say that a vernacular is distinguished from a language variant by differences in lexicon under common grammar.

\section{Purpose of the Study}

Out of these speculations arises the question of connection between urban vernacular and national language: in case of weakening or breaking the connection it would be possible to speak about the formation of a national variant of some language. Thus, we consider that singling out of a language variant should be based on internal but not external or temporary (social, political) factors. If we do not take into account purely lexical aspect of urban vernacular, we may say that currently, at least in Crimea and Sevastopol, grammar and phonetics of urban vernacular correlates with contact vernacular as with the main means of everyday communication in different spheres in conditions of regular social contacts. So, we may assume that it is in vernacular where the language is realized beyond its literary norm which is considered an external factor for the language system.

\section{Research Methods}

Current research was conducted on the basis of field research of the speech of Sevastopol residents and inhabitants of the nearby villages. Dialectological method is the leading one being considered as a unity of ways and techniques of collecting, processing and interpreting dialectal material. In addition, in the process of collecting historical and linguistic material biographical method is used. It is traditionally applied in sociolinguistics and involves receiving such data from the interviewee as family background, mother tongue, language(s) used in the family and the closest surrounding, language of school education, migration(s) (if any) and their connection with language change, et cetera.

\section{Findings}

To illustrate the points discussed above we provide practical material gathered in the process of monitoring of the the Russian language functioning in Sevastopol conducted by the initiative of Sevastopol City Council within the framework of "The Programme of Developing Regional Russian Language and Russian Culture in Sevastopol in 2007-2011", as well as data collected by D. Romanchenko in 2015 which allow at least to superficially judge about the changes in the speech of Sevastopol residents. Monitoring was conducted for 7 months during which practical material was collected. Besides, all issues of the local newspaper "Slava Sevastopolya" for some years were turned into digital format and students of the Philology Department recorded the speech of local residents in informal situations (in public transport and public places).

As while studying the Russian language there was no goal to systematically describe the phonetic system with experimental methods, the observations proposed below are more of qualitative character.

Absence of convergence of sounds [i] and [i]. In the vowel system of Sevastopol residents there are no particular differences which rejects the idea of influence of the Ukrainian language. For instance, there is no articulatory convergence of sounds [i] and [i] which can be found in the Russian language functioning in the south of Ukraine, particularly in Odessa (Stepanov, 2004, pp. 94-102). 
There is no erroneous usage of graphemes и and ы in the writing of schoolchildren which could hypothetically happen as a result of the Ukrainian vowel system influence.

This allows to claim that there is no influence of the Ukrainian language on the Russian language in Sevastopol by the criterion of articulatory convergence of sounds [i] and [i].

Absence of diphthongisation of stressed vowels. Southern Russian dialects are characterised by diphthongisation which could be assumed to be present in the speech of Sevastopol residents as the speakers of this dialect. At the same time, another type of diphthongisation is characteristic of the Russian language in the south of Ukraine. The presence of such diphthongisation in the speech of Sevastopol residents could be considered as a sign of the Ukrainian language influence or realisation of the southern Russian dialectal features, however, this process was not witnessed. It allows us to state that by this criterion there is no influence of either the Ukrainian language or the Russian dialects on the vowel system of Sevastopol residents.

Reduction of vowels in an unstressed position. In the speech of Sevastopol residents we may consistently observe full 'akanie' (pronunciation of unstressed $<_{0}>$ as [a]) characteristic of the Russian literary language and 'ikanie' (pronunciation of unstressed $<\mathrm{e}>$ and $<$ ' $\mathrm{a}>$ as [i]) in positions after soft consonants. Consequently, if we may assume the presence of vowel reduction peculiarities in the speech of Sevastopol residents in comparison with the Russian literary norm, we may say that it is qualitative only, as more details concerning this reduction require experimental research.

Soft consonants. If the variant of the Russian language was formed under the influence of Ukrainian, we could expect the appearance of semi-soft consonants in the speech of Sevastopol residents as it is found in the speech of Odessa residents, however, this trend has not been observed. Moreover, let us remark that it is more usual for the speakers of the Ukrainian language and natives of Ukraine who for some time reside in Sevastopol to regularly use soft consonants instead of the Ukrainian semi-soft ones.

Phonemes $\langle\mathrm{v}\rangle$ and $\left\langle\mathrm{v}^{\prime}\right\rangle$. In the speech of Sevastopol residents phonemes $\langle\mathrm{v}\rangle$ and $\left\langle\mathrm{v}^{\prime}\right\rangle$ are regularly realised by bilabial sounds turning voiceless close to $[f]$ and [ $\left.f^{\prime}\right]$ even in the speech of ethnic

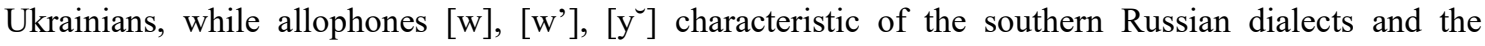
Ukrainian language are hardly ever met.

Phonemes $\langle\mathrm{g}\rangle,\langle\mathrm{g}\rangle,\langle\gamma\rangle$ and $\left\langle\gamma^{\prime}\right\rangle$. In the speech of Sevastopol residents voiced back consonants have predominantly plosives character but are often realised as $[\gamma]$ and $\left[\gamma^{\prime}\right]$, although such pronunciation is perceived by locals as vernacular. Along with that, devocalisation of back consonants $[\mathrm{k}]$ and $\left[\mathrm{k}^{\prime}\right],[\mathrm{x}]$ and $\left[\mathrm{x}^{\prime}\right]$ is witnessed which signals deviation from the norm and similarity of the speech of Sevastopol residents in this aspect to the southern Russian dialect and the Ukrainian language. At the same time, we may assume presence of $\langle\gamma\rangle$ and $\left\langle\gamma^{\prime}\right\rangle$ in contact vernacular as a variant of weak orthoepic norm.

Word-formation in connection with vocabulary. Locality is the main sphere of applying derivational means in Sevastopol. There is a wide range of agoronyms, godonyms, horonyms. Sevastopol urbanonyms are represented only by nominals and created by suffixation. Unfortunately, no new verbs have been registered. In 2007 there were such words as Artbuchta, Studgorodok (univerbation). In 2014, according to Master's thesis "Onomastics of the city of Sevastopol" by Romanchenko (2015), there was such phrase as 'on Gerstale' (on Geroev Stalingrada). In 2007 feminine horonyms ending in - $k a$ were in wide circulation: Vorotsovka (Vorontsov market), Kazachka (Kazachya bay), Korabelka (Korabelnaya 
side), Koshka (Matros Koshka street), Malashka (Malakhov hill), Strelka (Streletskaya bay), Tekhnichka (Technical library), Khrustalka (cape Khrustalniy), Khryushka (General Khryukin street), Yumashka (Yumashev street). According to D. Romanchenko, in 2015 this group of words was enlarged: Bastionka (2nd Bastion street), Voenka (Military post), Galinka (Galina Petrova street), Karantinka (Karantinnaya bay), Kozhanka (Kozhanov street), Ushaki (Ushakov square), Komsomolka (Komsomolskiy park), Maksimka (Maksimov dacha), Omezhka (Omega beach), Pozharka (Pozharov street), Sapunka (Sapun mountain), Budka (Budishchev street), Tsentralka (Tsentralniy market), which proves the productivity of this word-building model in Sevastopol. City districts and localities were named in the forms of pluralia tantum: Bombory (area of the 1st and 2nd Bombardment streets), Gogolya (Gogol street area), Kamyshi (Kamyshivaya bay area), Kephaly (Gorge Kephalovrisi area), Koloba (Kolobov street area), Kuliki (Kulikovo pole street area), Lyotchiki (Letchiki street area), Mekeshki (Mekenzie hills area), Ostryaki (General Ostryakov prospect area), Pyataki (the 5th district), Khrustali (Khrustalyov street area). According to our observations, these urbanonyms are not so frequently witnessed in recent years. In addition, new urbanonyms are often created with the help of metaphor and metonymy which is very widespread in the Russian word-building in general.

At the same time, with the exception of a few words (for example, 'gol'f' (golf), 'vodolazka' (rollneck sweater)) the lexicon of Sevastopol residents almost fully corresponds with the lexicon of the Russian language, which helps to explain the absence of vivid word-building patterns in the local speech and fits coinages into the word-building system of the Russian literary language.

Syntactic models (phrases (for example, verb government where there could be a room for variation) and sentences (where it is believed to be less variation)) were not separately analysed, however, from general observations we may say that there are no substantial differences in this sphere.

Summing up, we may say that the only systematic peculiarity in the speech of Sevastopol residents is wide use of sounds $[\gamma]$ and $\left[\gamma^{\prime}\right]$ and their devocalisation into $[\mathrm{x}]$ and $\left[\mathrm{x}^{\prime}\right]$, which may raise the question of $\langle\gamma\rangle$ and $\left\langle\gamma^{\prime}\right\rangle$ phonemes' functioning as a weak norm in contact vernacular

\section{Conclusion}

Judging from our observations of 2007 and D. Romanchenko material of 2015 it would be groundless to state that Sevastopol has any kind of variant of the Russian language different from the national one. On the contrary, the speech of Sevastopol residents is characterised by high similarity with the subsystems of the Russian literary language which allows to speak about general Russian contact vernacular with some lexical peculiarities being in circulation in Sevastopol that is a common feature of all more or less spatially detached language communities.

The fact that Sevastopol has contact vernacular practically identical to the general Russian one calls into question the assumption that some other variants of the language function in other towns of Crimea, for example, Ukrainian variant of the Russian language proposed by A. Rudyakov, as Sevastopol residents constantly contact with the inhabitants of other residential areas and the difference between their language systems would not only be noticeable but also would undoubtedly become the subject of separate reflection which would definitely be pointed out by the informants of both Sevastopol and Crimea. 


\section{References}

Amirov, V. (2021). Osobennosti funktsionirovaniia onomasticheskikh edinits v militarnom diskurse vooruzhennogo konflikta na vostoke Ukrainy [Functional Features of Onomastic Units in the Military Discourse of the Donbass Conflict]. Voprosy onomastiki [Problems of Onomastics], 18(1), 237-250. https://doi.org/10.15826/vopr_onom.2021.18.1.012

Antonenko, N., \& Teplova, T. (2019). Dialectological description of the Russian language functioning in the Baidar valley of greater Sevastopol. SHS Web of Conferences, 00006-00006. https://doi.org/10.1051/shsconf/20196900006

Bobrik, M. (2021). Mekhanizmy pragmatikalizacii $\mathrm{v}$ istorii russkoj formuly proshchaniya schastlivo! [Pragmaticalization mechanisms in the history of the Russian farewell formula sčastlívo!]. Voprosy yazykoznaniya [Topics in the Study of Language], 1, 70-83. https://doi.org/10.31857/0373-658X.2021.1.70-83

Chobanyan, K., Shchepilova, G., \& Zhukov, D. (2020). The new reality: Crimean and Sevastopol television after 2014. Russian Journal of Communication, 12(2), 171-186. https://doi.org/10.1080/19409419.2020.1825054

D’Arcey, J., Oraby S., \& Fox Tree, J. (2019). Wait Signals Predict Sarcasm in Online Debates. Dialogue \& Discourse, 10(2), 56-78. https://doi.org/10.5087/dad.2019.203

Fedorova, O. (2018). O russkoj zhestikulyacii s lingvisticheskoj tochki zreniya (k vyhodu monografii E. A. Grishinoj) [Russian gestures from a linguistic perspective (dedicated to the publication of Elena A. Grishina's monograph)]. Voprosy yazykoznaniya [Topics in the Study of Language], 5, 114123. https://doi.org/10.31857/S0373658X0001400-9

Gantsovskaia, N., \& Neganova, G. (2020). 18th Mezhdunarodnaia nauchnaia konferentsiia "Onomastika Povolzh'ia" [18th International Scientific Conference "Onomastics of the Volga Region"]. Voprosy onomastiki [Problems of Onomastics], 17(3), 339-343.

Khimik, V. (1998). Sovremennoe russkoe prostorechie kak dinamicheskaia sistema [Modern Russian vernacular as a dynamic system]. http://www. fixed.ru/prikling/conf/stilsist3/sovredygfwrl.html

Kudirka, R. (2019). Morphology and Adaptation Features of the Slang Suffixal Adverbs in Lithuanian Language: Hybrid Derivatives of Suffix -ai from Suffixal Adjectives of Russian. Respectus Philologicus, 36(41), 47-59. https://doi.org/10.15388/RESPECTUS.2019.36.41.22

Kudriavtseva, L. (2005). Iazyk goroda: obshchii sleng [Language of the city: common slang]. http://www.russian.kiev.ua/ archives/2005/0512/051220ct01.shtml

Malysheva, A., \& Ronko, R. (2020). Russkij ob"ektnyj genitiv pri otricanii po dannym dialektnyh korpusov i ustnogo korpusa NKRYA [Russian object genitive of negation in modern dialect corpora and oral subcorpus of RNC]. Voprosy yazykoznaniya [Topics in the Study of Language], 4, 25-54. https://doi.org/10.31857/0373-658X.2020.4.25-54

Nemickiene, Z. (2019). Means of Expression of Epistemic Modality in Russian Political Discourse. Respectus Philologicus, 36(41), 19-31. https://doi.org/10.15388/RESPECTUS.2019.36.41.20

Neshkovska, S. (2020). The Anti-language in the English as a Foreign Language Curriculum. Respectus Philologicus, 37(42), 47-61. https://doi.org/10.15388/RESPECTUS.2020.37.42.38

Romanchenko, D. (2015). Onomastikon goroda Sevastopolia [Onomasticon of the city of Sevastopol] [Master's thesis]. Moscow State University.

Rovnova, O. (2020). Money in Economic Activity and Language of the Old Believers of the South America. Slavistica Vilnensis, 65(2), 65-82. https://doi.org/10.15388/SlavViln.2020.65(2).48

Rozina, R. (2002). Kategoricheskii sdvig aktantov v semanticheskoi derivatsii. Voprosy iazykoznaniia [Topics in the Study of Language], 2, 3-15.

Rudyakov, A. (2010). Georusistika - rusistika 21 veka [Georussistics. Russian studies of the 21 st century]. In A. Rudyakov (Ed.), Georusistika. Pervoe priblizhenie [Georussistics. First approach] (pp. 8-21). Antikva.

Selmistraitis, L., \& Boikova, R. (2020). Source Domains of Smell Related Metaphorical Collocations: Study Based on Corpus of Contemporary American English. Respectus Philologicus, 38(43), 1124. https://doi.org/10.15388/RESPECTUS.2020.38.43.54 
Shalina, I. (2009). Ural'skoe gorodskoe prostorechie: vozmozhnosti lingvokul'turologicheskoi interpretatsii [Ural urban vernacular: the possibilities of linguocultural interpretation]. Izvestiia Ural'skogo gosudarstvennogo universiteta. Seriya 2. Gumanitarnyye nauki [Izvestia. Ural State University Journal. Series 2. Humanities and Arts], 63(1-2), 15-23.

Shmeleva, T. (2014). Onomastikon rossiyskogo goroda [Onomasticon of the Russian city]. LAP LAMBERT Academic Publishing.

Sitko, Yu. (2017). Konferentsiia "Dialektnyi slovar' kak lingvisticheskii resurs" Conference "Dialectal Dictionary as a Linguistic Resource"]. Vestnik Moskovskogo universiteta. Seriia 9: Filologiia [Moscow University Philology Bulletin], 4, 269-270.

Stepanov, E. (2004). Rosiis'ke movlennia Odesi [Russkiy yazyk Odessy]. Astro-print.

Terkulov, V. (2012). Regiolekt ili natsional'nyi variant: k postanovke problemy [Regiolekt ili natsional'nyy variant: k postanovke problemy]. Filologiia i kul'tura [Philology and Culture], 2(28), $117-120$.

Uryson, E. (2020). Analogiya v semantike i problemy semanticheskogo metayazyka (na primere sushchestvitel'nogo VNIMANIE) [Analogy in semantics and semantic metalanguage issues: The case of Russian VNIMANIE 'attention']. Voprosy yazykoznaniya [Topics in the Study of Language], 5, 57-75. https://doi.org/10.31857/0373-658X.2020.5.57-75 